\title{
Implementasi model problem-based learning seting student team achievement division dalam meningkatkan kemampuan pemecahan masalah dan minat belajar matematika
}

\author{
Siti Rahmalia Natsir ${ }^{\mathrm{a}, 1, *}$, Samritin ${ }^{\mathrm{a}, 2}$ \\ ${ }^{a}$ Universitas Muhammadiyah Buton, Jl. Betoambari, Kota Bau-Bau, Sulawesi Tenggara 93724, Indonesia \\ ${ }^{1}$ rahmalianatsir20@gmail.com * \\ * Korespondensi Penulis
}

Article history

Received June 26, 2020

Revised June 26, 2020

Accepted June 27, 2020

Available Online June 30, 2020

\section{Keywords}

Improving

Problem solving skill

Problem-based learning

STAD

Kemampuan pemecahan masalah

Minat belajar matematika
The purpose of this study is to describe the results of the application and application of the Problem-Based Learning learning model in the STAD type cooperative settings in improving problem-solving abilities and students' interest in learning mathematics. This research is a type of $C A R$. The subjects in this class action research of Va SD Negeri 2 Baubau elementary school. Data were collected using tests of problemsolving abilities, questionnaire interest in learning mathematics and observation. Evaluation of first cycle obtained an average grade of 60.71 with the percentage of students' learning ability $40.63 \%$ and interest in learning mathematics in the very high category had a percentage of $6.25 \%$, the high category had a percentage of $25 \%$ and the medium category had a percentage $38 \%$ and low category had a percentage of $31 \%$. In first cycle, the learning performance was $92 \%$. In second cycle, the average class is 85.71 with the percentage of students' learning ability $90.63 \%$ and the interest in learning mathematics in the very high category has a percentage of $28.39 \%$, the high category has a percentage of 59\% and the medium category as a percentage of $13 \%$ and $0 \%$ of the interest in categories is low and very low. Implementation of learning by $97 \%$. Based on the results of research and discussion, it can be concluded that the application of the $P B L$ setting STAD can improve the problem solving skill and students' interest in learning mathematics. 
Penelitian ini bertujuan untuk mendaskripsikan hasil penerapan Problem-Based Learning (PBL dalam seting kooperatif tipe Student Team Achievement Division (STAD) dalam meningkatkan kemampuan pemecahan masalah dan minat belajar matematika. Penelitian ini termasuk jenis Penelitian Tindakan Kelas (PTK). Subjek dalam penelitian tindakan kelas ini adalah kelas Va SD Negeri 2 Baubau sebanyak 32 murid. Data dikumpulkan menggunakan tes kemampuan pemecahan masalah, angket minat belajar matematika dan lembar observasi. Evaluasi siklus pertama diperoleh nilai rata-rata kelas sebesar 60,71 dengan persentase kentutasan belajar murid-murid adalah 40,63\% dan minat belajar matematika pada katagori ST memiliki persentase $6,25 \%$, katagori $\mathrm{T}$ memiliki persentase $25 \%$, katagori $\mathrm{S}$ memiliki persentase $38 \%$ dan kategori $\mathrm{R}$ memiliki persentase 31\%. Pada siklus pertama keterlaksanaan pembelajaran $92 \%$. Siklus kedua rata-rata kelas 85,71 dengan persentase kentutasan belajar murid-murid adalah 90,63\% dan minat belajar matematika pada katagori ST memiliki persentase 28,39\%, katagori T memiliki persentase 59\% dan katagori S memiliki persentase $13 \%$ dan $0 \%$ minat dalam ketegori $\mathrm{R}$ dan sangat SR. Keterlaksanaan pembelajaran sebesar $97 \%$. Berdasarkan hasil penelitian dan pembahasan, maka dapat disimpulkan bahwa penerapan model PBL dalam seting STAD dapat meningkatkan kemampuan pemecahan masalah dan minat belajar matematika murid-murid.

This is an open access article under the CC-BY-SA license.

\section{Pendahuluan}

Matematika merupakan salah satu bidang studi yang menurut beberapa murid Sekolah Dasar (SD) merupakan bidang studi yang cukup sulit. Permendikbud No 21 Tahun 2016 menyebutkan beberapa kemampuan yang harus dikuasai pada bidang studi matematika pada tingkat SD, dimana kemampuan yang dimaksud yaitu: 1) Menunjukan sikap positif yang positif dalam menyelesaikan masalah matematika, yakni bersikap logis, cermat, teliti, jujur, bertanggung jawab, dan tidak mudah menyerah; 2) Memiliki keingintahuan, semangat belajar secara terus menerus, self efficacy, serta minat yang tinggi pada matematika, yang terbentuk melalui proses belajar; 3) Memahami, mengidentifikasi, menyelesaikan masalah serta menggunakan model konkret dalam menyelesaikan masalah. Namum yang terjadi dilapangan berdasarkan hasi wawancara dengan guru kelas Va pada SD Negeri 2 Baubau, sebagian besar kemampuan pemecahan masalah matematis siswa tergolong rendah. Hal ini sejalan dengan hasil observasi awal pada murid yaitu tes Kemampuan Pemecahan Masalah (KPM) dengan peresentase ketuntasan sebesar 28,13\% khususnya pada materi pecahan. Selain itu, minat dalam mempelajari matematika masih tergolong rendah. Hasil angket minat belajar matematika Sekolah Dasar Negeri (SDN) 2 Baubau dapat dilihat pada Tabel 1.

Tabel 1. Data Minat Belajar Matematika

\begin{tabular}{ccc}
\hline Kriteria & $\begin{array}{c}\text { Banyak } \\
\text { Siswa }\end{array}$ & Presentase \\
\hline Sangat Tinggi & 0 & $0 \%$ \\
Tinggi & 4 & $13 \%$ \\
Sedang & 11 & $34 \%$ \\
Rendah & 12 & $38 \%$ \\
Sangat Rendah & 5 & $16 \%$ \\
\hline
\end{tabular}

Masalah yang terjadi di atas akibat beberapa faktor baik faktor dari internal siswa itu sendiri ataupun faktor dari luar seperti pelaksanaan pembelajaran, keadaan sekolah dan lain sebagainya. Akan tetapi yang menjadi sorotan pada penelitian ini adalah proses belajar mengajar (PBM) matematika dimana guru jarang mengimplementasikan PBM yang bervariasi dan menyenangkan, guru cenderung menggunakan pembelajaran tradisional. Oleh karena itu pembelajaran cendrung 
monoton dan kurang melibatkan aktifitas kemampuan pemecahan masalah (KPM) yang bersifat kooperatif sehingga menyebabkan murid menjadi kesulitan jika dihadapkan dengan soal yang berbasis masalah dan kurang termotivasi untuk belajar matematika.

Pembelajaran yang aktif, efektif, kreatif, dan menyenangkan diperlukan untuk membantu mengatasi masalah-masalah yang telah dipaparkan sebelumnya. Salah satu model pembelajaran yang dapat dikembangkan sebagai usaha dalam meningkatkan PBM dan untuk meningkatkan peran aktif siswa adalah Problem-Based Learning (PBL) dan Student Team Achievement Division (STAD).

PBM dengan PBL tidak hanya sekedar membaca, mendengarkan penjelasan guru dalam menyampaikan materi pada bidang studi tertentu, tetapi juga menyelesaikan masalah-masalah realistik yang dialami dalam kehidupan setiap hari (Djidu \& Jailani, 2018a, 2018b; Mashuri et al., 2019; Mergendoller, Maxwell, Besellino, 2006: 49). Pada kenyataannya, siswa sangat sulit untuk menguasai kompetensi-kompetensi berpikir sacara logis, kritis, kreatif, inovatif dan penalaran apabila guru menerapkan metode pembelajaran yang kurang bervariasi.

Bagian dari model pembelajaran yang mampu menimimalisir kesulitan siswa dalam pemecahan masalah yaitu model pembelajaran kooperatif tipe STAD. Penelitian yang dilakukan oleh Carlan, Rubin \& Morgan (2005), menyimpulkan bahwa: (1) melalui pembelajaran kooperatif murid-murid lebih aktif terlibat dalam memecahkan masalah matematika; (2) murid-murid beralih dari sikap kompetitif menjadi sikap kooperatif atau mulai berbagi ide jawaban mengenai masalah yang mereka hadapi; (3) pada awalnya siswa saling bertanya untuk jawaban mereka, mulai beralih untuk saling membantu satu sama lain pada proses pemecahan masalah matematika.

Selain itu, untuk meningkatkan peran aktif para murid dalam pemecahan masalah, saat ini model pembelajaran tipe STAD adalah model pembelajaran yang paling banyak digunakan pada bidang studi matematika, para ahli menyimpulkan bahwa model ini tidak hanya baik dalam membantu pelajar memahami konsep-konsep matematika.

Slavin (2006: 256) menjelaskan bahwa setiap murid ditugaskan untuk membentuk kelompokkelompok belajar dimana setiap kelompok beranggotakan empat orang yang terdiri dari kemampuan, jenis kelamin dan suku yang berbeda-beda. Guru menjelaskan pelajaran dan kemudian murid bekerja pada kelompok masing-masing dan saling membantu satu sama lain guna mencapai tujuan pembelajaran. Guru memberikan kuis kepada para murid, dan murid bekerja secara mandiri dalam menyelesaikan kuis. Berdasarkan pendapat Slavin, model pembelajaran tipe STAD selain menumbuhkan peran aktif murid, juga dapat membantu menumbuhkan KPM para murid, ini ditunjukan dengan murid-murid tolong menolong dalam menyelesaikan masalah yang ditugaskan. Murid yang cerdas dapat membantu murid yang kurang cerdas dalam memahami materi.

Pembelajaran tipe STAD merupakan suatu strategi belajar yang menempatkan murid-murid pada kelompok-kelompok kecil yang heterogen baik tingkat kemampuan latar belakang sosial ekonomi maupun suku yang berbeda dan saling ketergantungan dalam struktur tugas, tujuan dan hadiah. Dalam hal ini setiap anggota kelompok akan bekerja sama dalam menyelesaikan setiap masalah yang diberikan guru dan kerjasama belum berakhir jika salah satu anggota kelompok belum menguasai bagaimana cara menyelesaikan masalah tersebut.

Model pembelajaran PBL yang berorientasi pada masalah dan model pembelajaran tipe STAD yang mengutamakan kelompok belajar, diharapkan dapat meningkatkan kemampuan pemecahan masalah. Minat belajar matematika murid-murid dapat meningkat dengan adanya kerjasama yang terbentuk dalam kelompok yang memiliki kemampuan dan latar belakang yang berbeda.

Bertitik tolak dari latar belakang pemikiran di atas maka penulis mengadakan suatu penelitian penelitian tindakan kelas (PTK) dalam upaya meningkatkan kemampuan pemecahan masalah dan minat belajar matematika siswa kelas Va SDN 2 Baubau dengan mengimplelentasikan PBL dalam seting STAD.

Tujuan yang ingin dicapai dalam penelitian ini ada dua. Pertama, mendeskripsikan penerapan PBL dalam seting STAD pada kelas Va SD Negeri 2 Baubau. Kedua, mendeskripsikan hasil penerapan model pembelajaran PBL seting STAD dalam meningkatkan kemampuan pemecahan masalah dan minat belajar matematika para murid pada kelas Va SDN 2 Baubau. 
Penelitian ini diharapkan dapat memberikan manfaat, diantaranya secara teoritik, penelitian ini dapat membantu perkembangan pengetahuan khususnya terkait dengan student worksheet dan model pembelajaran variatif dalam pembelajaran matematika, memberikan pembelajaran alternatif yang dapat digunakan dalam proses pembelajaran khususnya matematika dalam rangka meningkatkan kemampuan pemecahan masalah dan minat belajar matematika siswa dan dengan model pembelajara PBL dalam seting STAD diharapkan dapat melatih kemampuan pemecahan masalah matematika, kerjasama dan peran aktif serta minat belajar matematika para murid.

\section{Metode}

\subsubsection{Jenis Penelitian}

Penelitian ini menggunakan jenis penelitian tidakan kelas (PTK) model Jhon Eliot. Pelaksanaan tindakan siklus pertama, langkah pertama yakni observasi awal dengan memberikan pretest pemecahan masalah dan angket minat belajar matematika. Siklus pertama yakni tahap perencanaan tidakan dilanjutkan dengan kegiatan pembelajaran, kemudian evaluasi yakni pemberian posttest pemecahan masalah dan angket minat belajar matematika. Setelah itu dilakukan refleksi agar kekurangan-kekurangan dalam pembelajaran siklus pertama dapat dianalisis dan dilakukan revisi perencanaan. Pelaksanaan tindakan siklus kedua terdapat sebuah perencanaan baru berdasarkan revisi pada siklus pertama kemudian diterapkan pada kegiatan pembelajaran dan dilanjutkan dengan pemberian posttest pemecahan masalah dan angket minat belajar matematika. Pelaksanaan tindakan siklus dihentikan apabila telah mencapai kriteria keberhasilan tindakan.

\subsubsection{Waktu dan Tempat Penelitian}

PTK ini dilaksanakan di kelas Va SDN 2 Baubau yang berlokasi di kota Baubau. Pelaksanaan PTK ini akan dilaksanakan pada bulan Januari - Februari 2020. Subjek PTK ini yaitu murid-murid kelas Va SDN 2 Baubau sebanyak 32 murid. Alasan pemilihan kelas Va adalah karena berdasarkan hasil wawancara dengan guru, kelas ini merupakan kelas yang sebagain besar murid-muridnya memiliki kemampuan pemecahan masalah dan minat yang rendah dalam belajar khususnya matematika.

\subsubsection{Prosedur Penelitian}

PTK ini akan dilaksanakan pada materi pecahan. Setiap siklus terdapat 4 tidakan (tatap muka). Dimana setiap siklus dilaksanakan dengan menggunakan model pembelajaran PBL dalam seting STAD. Pelaksanaan tindakan siklus dihentikan apabila telah mencapai kriteria keberhasilan tindakan.

\subsubsection{Instrumen Penelitian}

Instrumen pengumpulan data dalam penelitian ini adalah tes uraian, angket dan observasi. Instrumen tes digunakan untuk mengumpulkan data kemampuan pemecahan masalah matematika murid-murid. Data kemampuan pemecahan masalah diperoleh melalui tes uraian yang berisi soalsoal kemampuan pemecahan masalah. Instrumen angket digunakan untuk mengumpulkan data minat belajar matematika murid-murid dengan menggunakan angket minat belajar matematika dan untuk mengumpulkan data keterlaksanaan pembelajaran baik kegiatan pembelajaran oleh peneliti maupun kegiatan murid-murid digunakan teknik observasi dengan meggnakan lembar observasi keterlaksanaan pembelajaran.

\subsubsection{Teknik Analisis Data}

Data yang diperoleh dari instrument tes kemampuan pemecahan masalah dianalsis guna mendeskripsikan KPM murid. Deskripsi KPM murid secara individu dianalisis dengan menggunakan ketercapaian nilai Kriteria Ketuntasan Minimal (KKM) yang ditetapkan oleh sekolah yaitu 70. Sedangkan untuk mendeskripsikan KPM murid secara keselurahan , data dianalis dengan menggunakan rumus ketuntasan klasikal (KK) yaitu jumlah murid mencapai KKM dibagi dengan jumlah murid secara keseluruhan dikali seratus persen. Adapun rumus KKM dapat dituliskan seperti pada persamaan (1).

$$
K K=\frac{J M}{J K} \times 100 \%
$$


Peningkatan kemampuan pemecahan masalah diperoleh dengan membandingkan persentase nilai ketuntasan klasikal murid pada siklus pertama dengan siklus selanjutnya. Jika siklus sesudahnya lebih besar dari siklus sebelumnya maka dikatakan bahwa terjadi peningkatan KPM dari para murid.

Data yang diperoleh dari pemberian angket minat belajar matematika murid dianalisis untuk mengetahui minat belajar matematika murid-murid. Persentase angket minat belajar matematika pada siklus pertama dan siklus selanjutnya dibandingkan untuk mengetahui adanya peningkatan minat belajar murid. Penskoran untuk angket minat belajar matematika dilakukan dengan menggunakan skala likert dengan membuat interval menjadi lima (5) kriteria yaitu sangat tinggi (ST), tinggi (T), sedang (S), rendah (R) dan sangat rendah(SR). Data yang diperoleh digolongkan dalam kriteria menurut Saifudin Azwar (2007) pada Tabel 2.

Tabel 2. Interval Nilai dan Kriteria

\begin{tabular}{cc}
\hline Interval Nilai & Kriteria \\
\hline $\mathrm{Mi}+1,5 \mathrm{Sbi}<\mathrm{Y}$ & $\mathrm{ST}$ \\
$\mathrm{Mi}+0,5 \mathrm{Sbi}<\mathrm{Y} \leq \mathrm{Mi}+1,5 \mathrm{Sbi}$ & $\mathrm{T}$ \\
$\mathrm{Mi}-0,5 \mathrm{Sbi}<\mathrm{Y} \leq \mathrm{Mi}+0,5 \mathrm{Sbi}$ & $\mathrm{S}$ \\
$\mathrm{Mi}-1,5 \mathrm{Sbi}<\mathrm{Y} \leq \mathrm{Mi}-0,5 \mathrm{Sbi}$ & $\mathrm{R}$ \\
$\mathrm{X} \leq \mathrm{Mi}-1,5 \mathrm{Sbi}$ & $\mathrm{SR}$
\end{tabular}

Kriteria keberhasilan murid-murid untuk KPM yaitu minimal MURID-MURID yang mencapai KKM di atas 50\%. Dimana setiap murid dinyatakan tuntas ketika skor yang didapatkan $\geq 70$. Sedangkan untuk angket minat belajar matematika target yang diinginkan yakni $0 \%$ minat belajar matematika siswa pada kategori rendah dan sangat rendah.

\section{Hasil dan Pembahasan}

\subsection{Hasil}

\subsubsection{Siklus Pertama}

Kegiatan PBM pada siklus pertama berlangsung dalam 4 pertemuan. Sebelum siklus pertama dilaksanakan, peneliti memberikan pretest dan angket minat belajar matematika untuk mengetahui KPM awal murid-murid dan minat terhadap matematika. Masing-masing pertemuan berlangsung $3 \mathrm{x}$ 35 menit. Sedangkan evaluasi berlangsung selama 60 menit pada pertemuan kelima.

Tabel 3.

Tahapan Kegiatan Siklus Pertama

\begin{tabular}{|c|c|}
\hline Tahapan & Kegiatan \\
\hline Perencanaan Tindakan & $\begin{array}{l}\text { - Mengkaji langkah-langkah dalam pembelajaran } \\
\text { PBL dalam seting kooperatif tipe STAD. } \\
\text { Menyusun perangkat pembelajaran siklus pertama } \\
\text { seperti silabus, RPP, dan LKS } \\
\text { - Menyiapkan lembar observasi kegiatan peneliti } \\
\text { dan murid-murid siklus pertama. } \\
\text { - Menyiapkan soal pemecahan masalah siklus } \\
\text { pertama beserta kunci jawabannya. } \\
\text { Menyiapkan angket untuk mengukur minat belajar } \\
\text { matematika pada siklus pertam }\end{array}$ \\
\hline
\end{tabular}

Kegiatan PBM siklus pertama pertemuan pertama dilaksanakan pada tanggal 13 Januari 2020. Dalam penelitian ini peneliti bertindak sebagai guru dan teman seprofesi bertindak sebagai observer. Pada pertemuan pertama, peneliti menjelaskan kepada murid bahwa pada pertemuan pertama dan selanjutnya akan dilaksanakan proses pembelajaran yang agak berbeda terkait dengan PTK.

Selesai memberikan arahan kepada murid, peneliti memberikan apersepsi dan menjelaskan tujuan pembelajaran. Sebelum membagi murid kedalam beberapa kelompok peneliti memberikan sedikit informasi terhadap materi yang akan dipelajari. Peneliti meminta murid untuk membentuk kelompok, dimana setiap kelompok terdiri dari 4 orang, sehingga terdapat 8 kelompok dalam kelas Va.

Peneliti memberikan LKS 1 dan lembar informasi yang berisi materi penjumlahan pecahan kepada masing-masing kelompok untuk didiskusikan dan diselesaikan. Sebelum menyelesaikan 
masalah pada LKS 1, murid diminta untuk membaca terlebih dahulu informasi-informasi yang berkaitan dengan penjumlahan pecahan baik dari lembar informasi maupun buku referensi tambahan dan peneliti memberikan bimbingan kepada masing-masing kelompok. Pada tahap ini murid masih kesulitan dalam memahami sendiri informasi yang diberikan. Masing-masing kelompok mengerjakan LKS 1 yang berisi masalah kehidupan sehari-hari yang berkaitan dengan penjumlahan pecahan yang akan dipecahan oleh para murid. Pada saat mengerjakan LKS 1 terlihat beberapa murid bekerjasama dan saling tanyajawab pada saat berdiskusi, terdapat beberapa murid yang masih terlihat menggaggu teman sehingga terkadang mengakibatkan keributan dan beberapa kelompok juga terlihat masih ribut dan membicarakan hal lain diluar materi pada LKS 1. Pada tahap ini waktu yang digunakan cukup lama. Peneliti juga memberikan bimbingan kepada masing-masing kelompok apabila ada hal yang belum jelas dalam pengerjaan LKS 1 tersebut.

Setelah para murid mengerjakan secara berkelompok LKS 1, kemudian peneliti meminta salah satu kelompok menyajikan atau mempresentasikan hasil diskusi kelompoknya dan murid lain menanggapi. Peneliti juga memberikan konfirmasi terhadap hasil kerja kelompok, jawaban dan pertanyaan murid. Peneliti juga tidak memberikan penghargaan kepada setiap kelompok karena masalah waktu.

Kegiatan PBM pertemuan kedua siklus pertama dilaksanakan pada tanggal 15 Januari 2020. Sebelum pembelajaran dimulai, peneliti mengajak murid-murid untuk tenang dan mempersilahkan ketua kelas untuk memimpin doa. Peneliti mempersiapkan bahan pembelajaran yang akan digunakan. Selanjutnya Peneliti melakukan apersepsi dengan mengajukan beberapa pertanyaan terkait dengan masalah yang akan dipecahkan. Selain itu, peneliti juga menjelaskan apa yang harus dicapai (tujuan pembelajaran) pada hari itu.

Peneliti membagikan LKS 2 dan lembar informasi yang berisi materi pengurangan pecahan kepada masing-masing kelompok untuk didiskusikan dan diselesaikan. Sebelum menyelesaikan masalah pada LKS 2, murid-murid diminta untuk membaca terlebih dahulu informasi-informasi yang berkaitan dengan pengurangan pecahan baik dari lembar informasi maupun buku referensi tambahan dan peneliti memberikan bimbingan kepada tiap-tiap kelompok. Pada siklus pertama pertemuan kedua murid-murid mulai saling berdiskusi mengenai informasi-informasi yang ada pada lembar informasi. Tiap-tiap kelompok belajar mengerjakan LKS 2 yang berisi masalah kehidupan sehari-hari yang berkaitan dengan pengurangan pecahan. Terlihat beberapa murid berdiskusi secara tenang dan antusias, terlihat ketika beberapa murid pada tiap-tiap kelompok belajar saling menyampaikan pendapat dan membantu teman kelompok yang kesulitan dalam memahami materi maupun memecahkan masalah. Peneliti menghampiri tiap-tiap kelompok dan memantau muridmurid dalam mendiskusikan masalah yang harus diselesaikan serta peneliti memberikan bimbingan seadanya kepada kelompok belajar apabila terdapat hal yang belum dipahami dalam menyelesaikan masalah. Setelah menyelesaikan masalah pada LKS 2, peneliti meminta salah satu kelompok untuk menyajikan atau mempresentasikan hasil diskusi kelompoknya. Pada pertemuan ini terjadi tangapan dari kelompok belajar lainnya. Peneliti juga memberikan konfirmasi terhadap hasil kerja kelompokn, jawaban dan pertanyaan murid-murid.

Selanjutnya, peneliti mempersilahkan murid-murid yang melakukan presentasi untuk kembali ke tempat duduk masing-masing dengan meminta murid yang lainnya untuk memberika tepuk tangan kepada kelompok belajar yang melakukan presentasi. Ketika keadaan kelas sudah tenang kembali, peneliti memberikan kuis (tes) untuk dikerjakan oleh masing-masing murid. Kuis yang diberikan sebanyak 1 nomor. Dengan menggunakan waktu yang tersisa, murid-murid menyelesaikan tes yang diberikan oleh peneliti. Terliat para murid serius ketika menyelesaikan tes tersebut. Setelah selesai mengerjakan tes tersebut, Selanjutnya peneliti memberikan kata-kata pujian kepada kelompok belajar yang tampil pada saat itu sebagai bentuk penghargaan.

Pertemuan kedua peneliti tidak memberikan tugas rumah kepada murid-murid. Sebelum menutup kegiatan PBM, peneliti bersama murid-murid membuat kesimpulan mengenai materi yang dipelajari pada saat itu serta peneliti juga menyampaikan materi yang akan dipelajari pada pertemuan selanjutnya.

Kegiatan PBM pertemuan ketiga siklus pertma dilaksanakan pada tanggal 20 Januari 2020. Sebelum pembelajaran dimulai, peneliti mengajak murid-murid untuk tenang dan mempersilahkan ketua kelas untuk memimpin doa. Peneliti mempersiapkan bahan pembelajaran yang akan digunakan. Selanjutnya Peneliti melakukan apersepsi dengan mengajukan beberapa pertanyaan 
terkait dengan masalah yang akan dipecahkan. Selain itu, peneliti juga menjelaskan apa yang harus dicapai (tujuan pembelajaran) pada hari itu.

Peneliti membagikan LKS 3 dan lembar informasi yang berisi materi perkalian pecahan kepada masing-masing kelompok untuk didiskusikan dan diselesaikan. Sebelum menyelesaikan masalah pada LKS 3, murid-murid diminta untuk membaca terlebih dahulu informasi-informasi yang berkaitan dengan perkalian pecahan baik dari lembar informasi maupun buku referensi tambahan dan peneliti memberikan bimbingan kepada tiap-tiap kelompok. Pada siklus pertama pertemuan kedua murid-murid mulai saling berdiskusi mengenai informasi-informasi yang ada pada lembar informasi. Tiap-tiap kelompok belajar mengerjakan LKS 3 yang berisi masalah kehidupan seharihari yang berkaitan dengan perkalian pecahan. Terlihat beberapa murid berdiskusi secara tenang dan antusias, terlihat ketika beberapa murid pada tiap-tiap kelompok belajar saling menyampaikan pendapat dan membantu teman kelompok yang kesulitan dalam memahami materi maupun memecahkan masalah. Peneliti menghampiri tiap-tiap kelompok dan memantau murid-murid dalam mendiskusikan masalah yang harus diselesaikan serta peneliti memberikan bimbingan seadanya kepada kelompok belajar apabila terdapat hal yang belum dipahami dalam menyelesaikan masalah. Setelah menyelesaikan masalah pada LKS 3, peneliti meminta salah satu kelompok untuk menyajikan atau mempresentasikan hasil diskusi kelompoknya. Pada pertemuan ini terjadi tangapan dari kelompok belajar lainnya. Peneliti juga memberikan konfirmasi terhadap hasil kerja kelompokn, jawaban dan pertanyaan murid-murid.

Selanjutnya, peneliti mempersilahkan murid-murid yang melakukan presentasi untuk kembali ke tempat duduk masing-masing dengan meminta murid yang lainnya untuk memberika tepuk tangan kepada kelompok belajar yang melakukan presentasi. Ketika keadaan kelas sudah tenang kembali, peneliti memberikan kuis (tes) untuk dikerjakan oleh masing-masing murid. Kuis yang diberikan sebanyak 1 nomor. Dengan menggunakan waktu yang tersisa, murid-murid menyelesaikan tes yang diberikan oleh peneliti. Terliat para murid serius ketika menyelesaikan tes tersebut. Setelah selesai mengerjakan tes tersebut, selanjutnya peneliti memberikan kata-kata pujian kepada kelompok belajar yang tampil pada saat itu sebagai bentuk penghargaan.

Pertemuan ketiga ini peneliti memberikan tugas rumah kepada murid-murid. Sebelum menutup kegiatan PBM, peneliti bersama murid-murid membuat kesimpulan mengenai materi yang dipelajari pada saat itu serta peneliti juga menyampaikan materi yang akan dipelajari pada pertemuan selanjutnya. Peneliti menutup kegiatan PBM dengan salam dan doa.

Kegiatan PBM pertemuan keempat siklus pertama dilaksanakan pada tanggal 22 Januari 2020. Sebelum pembelajaran dimulai, peneliti mengajak murid-murid untuk tenang dan mempersilahkan ketua kelas untuk memimpin doa. Peneliti mempersiapkan bahan pembelajaran yang akan digunakan. Selanjutnya Peneliti melakukan apersepsi dengan mengajukan beberapa pertanyaan terkait dengan masalah yang akan dipecahkan. Selain itu, peneliti juga menjelaskan apa yang harus dicapai (tujuan pembelajaran) pada hari itu.

Peneliti membagikan LKS 4 dan lembar informasi yang berisi materi pembagian pecahan kepada masing-masing kelompok untuk didiskusikan dan diselesaikan. Sebelum menyelesaikan masalah pada LKS 4, murid-murid diminta untuk membaca terlebih dahulu informasi-informasi yang berkaitan dengan pembagian pecahan baik dari lembar informasi maupun buku referensi tambahan dan peneliti memberikan bimbingan kepada tiap-tiap kelompok. Pada siklus pertama pertemuan keempat murid-murid mulai saling berdiskusi mengenai informasi-informasi yang ada pada lembar informasi. Tiap-tiap kelompok belajar mengerjakan LKS 4 yang berisi masalah kehidupan seharihari yang berkaitan dengan pembagian pecahan. Terlihat beberapa murid berdiskusi secara tenang dan antusias, terlihat ketika beberapa murid pada tiap-tiap kelompok belajar saling menyampaikan pendapat dan membantu teman kelompok yang kesulitan dalam memahami materi maupun memecahkan masalah. Peneliti menghampiri tiap-tiap kelompok dan memantau murid-murid dalam mendiskusikan masalah yang harus diselesaikan serta peneliti memberikan bimbingan seadanya kepada kelompok belajar apabila terdapat hal yang belum dipahami dalam menyelesaikan masalah. Setelah menyelesaikan masalah pada LKS 4, peneliti meminta salah satu kelompok untuk menyajikan atau mempresentasikan hasil diskusi kelompoknya. Pada pertemuan ini terjadi tangapan dari kelompok belajar lainnya. Peneliti juga memberikan konfirmasi terhadap hasil kerja kelompoknya, jawaban dan pertanyaan murid-murid. 
Selanjutnya, peneliti mempersilahkan murid-murid yang melakukan presentasi untuk kembali ke tempat duduk masing-masing dengan meminta murid yang lainnya untuk memberika tepuk tangan kepada kelompok belajar yang melakukan presentasi. Ketika keadaan kelas sudah tenang kembali, peneliti memberikan kuis (tes) untuk dikerjakan oleh masing-masing murid. Kuis yang diberikan sebanyak 1 nomor. Dengan menggunakan waktu yang tersisa, murid-murid menyelesaikan tes yang diberikan oleh peneliti. Terliat para murid serius ketika menyelesaikan tes tersebut. Setelah selesai mengerjakan tes tersebut, Selanjutnya peneliti memberikan kata-kata pujian kepada kelompok belajar yang tampil pada saat itu sebagai bentuk penghargaan.

Pertemuan keempat peneliti memberikan tugas rumah kepada murid-murid. Sebelum menutup kegiatan PBM, peneliti bersama murid-murid membuat kesimpulan mengenai materi yang dipelajari pada saat itu dan meberitahukan bahwa pertemuan selanjutnya akan dilaksanakan tes KPM dan pemberian angket minat. Peneliti menutup kegiatan PBM dengan salam dan doa.

\subsubsection{Observasi Siklus Pertama}

Berdasarkan lembar observasi dan diskusi dengan guru kelas, terdapat beberapa kelemahan dalam pelaksanaan pembelajaran siklus pertama. Kelemahan-kelemahan pada siklus pertama dijelaskan pada Tabel 4.

Tabel 4. Kelemahan Siklus Pertama

\begin{tabular}{|c|c|}
\hline Aspek & Keterangan \\
\hline Pendahuluan & $\begin{array}{c}\text { Peneliti tidak banyak melakukan apersepsi dalam } \\
\text { pembelajaran }\end{array}$ \\
\hline Materi & $\begin{array}{l}\text { Peneliti tidak banyak membuat contoh dari materi ajar } \\
\text { pada lembar informasi }\end{array}$ \\
\hline Pengelolaan Waktu & $\begin{array}{c}\text { Beberapa kegiatan pembelajaran tidak terlaksana } \\
\text { disebabkan oleh penggunaan alokasi waktu yang } \\
\text { kurang baik }\end{array}$ \\
\hline Asesmen & $\begin{array}{l}\text { Pemberian kuis dan pemberian penghargaan kepada } \\
\text { tiap kelompok tidak terlaksana pada pertemuan } \\
\text { pertama, sedangkan pertemuan kedua peneliti tidak } \\
\text { memberikan tugas rumah karena alasan waktu }\end{array}$ \\
\hline Instruksi/Arahan & $\begin{array}{c}\text { Ketika peneliti memberikan arahan untuk } \\
\text { menyelesaikan masalah, terdapat beberapa murid yang } \\
\text { tidak memperhatikan serta mendengarkan penjelasan } \\
\text { peneliti }\end{array}$ \\
\hline Psikomotor & $\begin{array}{l}\text { Beberapa murid pada kempok belajar terlihat pasif } \\
\text { dalam mengelurkan pendapat dan beberapa murid } \\
\text { lainnya kurang dalam membantu teman dalam } \\
\text { memahami materi maupun menyelesaikan masalah }\end{array}$ \\
\hline
\end{tabular}

Kelemahan-kelemahan yang terjadi pada siklus pertama selanjutnya didiskusikan dengan guru kelas untuk merencanakan pembelajaran yang lebih baik lagi sesuai dengan model PBL dalam seting STAD. Evaluasi pada siklus pertama dilakukan dengan memberikan tes kemampuan pemecahan masalah dalam bentuk uraian sebanyak lima nomor. Data hasil evaluasi siklus pertama dapat dilihat pada Tabel 5, bahwa nilai rata-rata kelas yang diperoleh pada siklus pertama sebesat 60,71 dan persentase kentutasan belajar siswa sebesar 31,25\%.

Tabel 5. Hasil Tes Kemampuan Pemecahan Masalah Siklus Pertama

\begin{tabular}{cc}
\hline Hasil Siklus Pertama & Nilai \\
\hline Rata-rata & 60,71 \\
Nilai Terendah & 30 \\
Nilai Tertinggi & 80 \\
$\geq 70$ & 10 \\
$<70$ & 22 \\
\hline Ketuntasan Belajar (\%) & 31,25
\end{tabular}

Evaluasi pada siklus pertama juga dilakukan dengan memberikan angket minat belajar matematika. Berikut data minat belajar matematika siswa siklus pertama. Pada Tabel 6 , terlihat bahwa minat belajar matematika murid0murid pada katagori sangat tinggi (ST) memiliki persentase 6,25\%, katagori tinggi (T) memiliki persentase 25\%, katagori sedang (S) memiliki persentase 38\% dan kategori rendah (R) memiliki persentase $31 \%$. 
Tabel 6. Hasil Minat Belajar Matematika Siklus Pertama

\begin{tabular}{ccc}
\hline Kategori & Jumlah & $\begin{array}{c}\text { Persentase } \\
\mathbf{( \% )}\end{array}$ \\
\hline Sangat Tinggi & 2 & 6,25 \\
Tinggi & 8 & 25 \\
Sedang & 12 & 38 \\
Rendah & 10 & 31 \\
Sangat Rendah & 0 & 0 \\
\hline
\end{tabular}

\subsubsection{Tahap Refleksi Siklus Pertama}

Tindakan perbaikan pada siklus kedua dilakukan berdasarkan indentifikasi kekurang-kekurangan pada siklus pertama. Tindakan perbaikan tersebut disajikan pada Tabel 7.

Tabel 7. Tindakan Perbaikan Siklus Pertama pada Siklus Kedua

\begin{tabular}{|c|c|}
\hline Aspek & Keterangan \\
\hline Pendahuluan & $\begin{array}{l}\text { Peneliti lebih memperhatikan RPP khususnya dalam } \\
\text { menyampaikan apersepsi, tujuan pembelajaran diawal } \\
\text { pembelajaran, memberikan motivasi dan pemberian } \\
\text { informasi pada lembar informasi }\end{array}$ \\
\hline Materi & $\begin{array}{l}\text { Mengoptimalkan pengelolaan kelas terutama saat } \\
\text { memahami informasi dan berdiskusi }\end{array}$ \\
\hline Pengelolaan Waktu & Merencanakan alokasi waktu yang lebih efektif \\
\hline Asesmen & $\begin{array}{l}\text { Peneliti lebih mampu mengelola kelas dalam mendampingi } \\
\text { siswa memecahkan masalah }\end{array}$ \\
\hline Instruksi/Arahan & Pemberian informasi dalam LKS harus lebih jelas \\
\hline Psikomotor & $\begin{array}{c}\text { Mengajak siswa untuk lebih semangat dalam presentasi } \\
\text { hasil diskusi }\end{array}$ \\
\hline
\end{tabular}

\subsubsection{Siklus Kedua}

Kegiatan PBM pada siklus kedua berlangsung dalam 4 (empat) pertemuan. Tiap-tiap pertemuan berlangsung selama 3 × 35 menit dan evaluasi berlangsung selama 60 menit pada pertemuan kelima.

\begin{tabular}{|c|c|}
\hline Tahapan & Kegiatan \\
\hline Perencanaan Tindakan & $\begin{array}{l}\text { - Mendaftar kekurangan-kekurangan yang ada pada } \\
\text { siklus pertama } \\
\text { - Menyusun perangkat pembelajaran siklus kedua } \\
\text { yang merupakan revisi dari siklus pertama seperti } \\
\text { RPP, LKS dan lembar informasi } \\
\text { - Menyiapkan materi yang akan digunakan pada } \\
\text { siklus kedua } \\
\text { Menyiapkan lembar observasi kegiatan peneliti } \\
\text { dan siswa siklus kedua } \\
\text { - Menyiapkan soal evaluasi (tes kemampuan } \\
\text { pemecahan masalah) siklus kedua beserta kunci } \\
\text { jawabannya } \\
\text { Menyiapkan angket minat belajar matematika } \\
\text { pada siklus kedua }\end{array}$ \\
\hline
\end{tabular}

Kegiatan PBM pertemuan pertama siklus kedua dilaksanakan pada tanggal 3 Februari 2020. Sebelum pembelajaran dimulai, peneliti mengajak murid-murid untuk tenang dan mempersilahkan ketua kelas untuk memimpin doa. Peneliti mempersiapkan bahan pembelajaran yang akan digunakan. Selanjutnya Peneliti melakukan apersepsi dengan mengajukan beberapa pertanyaan terkait dengan masalah yang akan dipecahkan. Selain itu, peneliti juga menjelaskan apa yang harus dicapai (tujuan pembelajaran) pada hari itu.

Peneliti membagikan LKS 5 dan lembar informasi yang berisi materi pengurangan pecahan kepada masing-masing kelompok untuk didiskusikan dan diselesaikan. Sebelum menyelesaikan masalah pada LKS 5, murid-murid diminta untuk membaca terlebih dahulu informasi-informasi yang berkaitan dengan pengurangan pecahan baik dari lembar informasi maupun buku referensi tambahan dan peneliti memberikan bimbingan kepada tiap-tiap kelompok. Pada siklus kedua pertemuan pertama murid-murid mulai saling berdiskusi mengenai informasi-informasi yang ada pada lembar informasi. Tiap-tiap kelompok belajar mengerjakan LKS 5 yang berisi masalah 
kehidupan sehari-hari yang berkaitan dengan pengurangan pecahan. Terlihat beberapa murid berdiskusi secara tenang dan antusias, terlihat ketika beberapa murid pada tiap-tiap kelompok belajar saling menyampaikan pendapat dan membantu teman kelompok yang kesulitan dalam memahami materi maupun memecahkan masalah. Peneliti menghampiri tiap-tiap kelompok dan memantau murid-murid dalam mendiskusikan masalah yang harus diselesaikan serta peneliti memberikan bimbingan seadanya kepada kelompok belajar apabila terdapat hal yang belum dipahami dalam menyelesaikan masalah. Setelah menyelesaikan masalah pada LKS 5, peneliti meminta salah satu kelompok untuk menyajikan atau mempresentasikan hasil diskusi kelompoknya. Pada pertemuan ini terjadi tangapan dari kelompok belajar lainnya. Peneliti juga memberikan konfirmasi terhadap hasil kerja kelompokn, jawaban dan pertanyaan murid-murid.

Selanjutnya, peneliti mempersilahkan murid-murid yang melakukan presentasi untuk kembali ke tempat duduk masing-masing dengan meminta murid yang lainnya untuk memberika tepuk tangan kepada kelompok belajar yang melakukan presentasi. Ketika keadaan kelas sudah tenang kembali, peneliti memberikan kuis (tes) untuk dikerjakan oleh masing-masing murid. Kuis yang diberikan sebanyak 1 nomor. Dengan menggunakan waktu yang tersisa, murid-murid menyelesaikan tes yang diberikan oleh peneliti. Terliat para murid serius ketika menyelesaikan tes tersebut. Setelah selesai mengerjakan tes tersebut, Selanjutnya peneliti memberikan kata-kata pujian kepada kelompok belajar yang tampil pada saat itu sebagai bentuk penghargaan.

Pertemuan pertama siklus kedua ini peneliti memberikan tugas rumah kepada murid-murid. Sebelum menutup kegiatan PBM, peneliti bersama murid-murid membuat kesimpulan mengenai materi yang dipelajari pada saat itu serta peneliti juga menyampaikan materi yang akan dipelajari pada pertemuan selanjutnya. Peneliti menutup kegiatan PBM dengan salam dan doa.

Kegiatan PBM pertemua kedua siklus kedua dilaksanakan pada tanggal 5 Februari 2020. Sebelum pembelajaran dimulai, peneliti mengajak murid-murid untuk tenang dan mempersilahkan ketua kelas untuk memimpin doa. Peneliti mempersiapkan bahan pembelajaran yang akan digunakan. Selanjutnya Peneliti melakukan apersepsi dengan mengajukan beberapa pertanyaan terkait dengan masalah yang akan dipecahkan. Selain itu, peneliti juga menjelaskan apa yang harus dicapai (tujuan pembelajaran) pada hari itu.

Peneliti membagikan LKS 6 dan lembar informasi yang berisi materi penjumlahan pecahan kepada masing-masing kelompok untuk didiskusikan dan diselesaikan. Sebelum menyelesaikan masalah pada LKS 6, murid-murid diminta untuk membaca terlebih dahulu informasi-informasi yang berkaitan dengan penjumlahan pecahan baik dari lembar informasi maupun buku referensi tambahan dan peneliti memberikan bimbingan kepada tiap-tiap kelompok. Pada siklus kedua pertemuan kedua murid-murid mulai saling berdiskusi mengenai informasi-informasi yang ada pada lembar informasi. Tiap-tiap kelompok belajar mengerjakan LKS 6 yang berisi masalah kehidupan sehari-hari yang berkaitan dengan penjumlahan pecahan. Terlihat beberapa murid berdiskusi secara tenang dan antusias, terlihat ketika beberapa murid pada tiap-tiap kelompok belajar saling menyampaikan pendapat dan membantu teman kelompok yang kesulitan dalam memahami materi maupun memecahkan masalah. Peneliti menghampiri tiap-tiap kelompok dan memantau muridmurid dalam mendiskusikan masalah yang harus diselesaikan serta peneliti memberikan bimbingan seadanya kepada kelompok belajar apabila terdapat hal yang belum dipahami dalam menyelesaikan masalah. Setelah menyelesaikan masalah pada LKS 6, peneliti meminta salah satu kelompok untuk menyajikan atau mempresentasikan hasil diskusi kelompoknya. Pada pertemuan ini terjadi tangapan dari kelompok belajar lainnya. Peneliti juga memberikan konfirmasi terhadap hasil kerja kelompokn, jawaban dan pertanyaan murid-murid.

Selanjutnya, peneliti mempersilahkan murid-murid yang melakukan presentasi untuk kembali ke tempat duduk masing-masing dengan meminta murid yang lainnya untuk memberika tepuk tangan kepada kelompok belajar yang melakukan presentasi. Ketika keadaan kelas sudah tenang kembali, peneliti memberikan kuis (tes) untuk dikerjakan oleh masing-masing murid. Kuis yang diberikan sebanyak 1 nomor. Dengan menggunakan waktu yang tersisa, murid-murid menyelesaikan tes yang diberikan oleh peneliti. Terliat para murid serius ketika menyelesaikan tes tersebut. Setelah selesai mengerjakan tes tersebut, Selanjutnya peneliti memberikan kata-kata pujian kepada kelompok belajar yang tampil pada saat itu sebagai bentuk penghargaan.

Pertemuan keuda siklus kedua ini peneliti memberikan tugas rumah kepada murid-murid. Sebelum menutup kegiatan PBM, peneliti bersama murid-murid membuat kesimpulan mengenai 
materi yang dipelajari pada saat itu serta peneliti juga menyampaikan materi yang akan dipelajari pada pertemuan selanjutnya. Peneliti menutup kegiatan PBM dengan salam dan doa.

Kegiatan PBM pertemua ketiga dan keempat dilaksanakan pada tanggal 10 dan 12 Februari 2020. Sebelum pembelajaran dimulai, peneliti mengajak murid-murid untuk tenang dan mempersilahkan ketua kelas untuk memimpin doa. Peneliti mempersiapkan bahan pembelajaran yang akan digunakan. Selanjutnya Peneliti melakukan apersepsi dengan mengajukan beberapa pertanyaan terkait dengan masalah yang akan dipecahkan. Selain itu, peneliti juga menjelaskan apa yang harus dicapai (tujuan pembelajaran) pada hari itu.

Peneliti membagikan LKS 7 dan LKS 8 dan lembar informasi yang berisi materi perkalian dan pembagian pecahan kepada masing-masing kelompok untuk didiskusikan dan diselesaikan. Sebelum menyelesaikan masalah pada LKS 7 dan LKS 8, murid-murid diminta untuk membaca terlebih dahulu informasi-informasi yang berkaitan dengan perkalian dan pembagian pecahan baik dari lembar informasi maupun buku referensi tambahan dan peneliti memberikan bimbingan kepada tiaptiap kelompok. Pada siklus kedua pertemuan ketiga dan keempat murid-murid mulai saling berdiskusi mengenai informasi-informasi yang ada pada lembar informasi. Tiap-tiap kelompok belajar mengerjakan LKS 7 dan LKS 8 yang berisi masalah kehidupan sehari-hari yang berkaitan dengan perkalian dan pembagian pecahan. Terlihat beberapa murid berdiskusi secara tenang dan antusias, terlihat ketika beberapa murid pada tiap-tiap kelompok belajar saling menyampaikan pendapat dan membantu teman kelompok yang kesulitan dalam memahami materi maupun memecahkan masalah. Peneliti menghampiri tiap-tiap kelompok dan memantau murid-murid dalam mendiskusikan masalah yang harus diselesaikan serta peneliti memberikan bimbingan seadanya kepada kelompok belajar apabila terdapat hal yang belum dipahami dalam menyelesaikan masalah. Setelah menyelesaikan masalah pada LKS 7 dan LKS 8, peneliti meminta salah satu kelompok untuk menyajikan atau mempresentasikan hasil diskusi kelompoknya. Pada pertemuan ini terjadi tangapan dari kelompok belajar lainnya. Peneliti juga memberikan konfirmasi terhadap hasil kerja kelompokn, jawaban dan pertanyaan murid-murid.

Selanjutnya, peneliti mempersilahkan murid-murid yang melakukan presentasi untuk kembali ke tempat duduk masing-masing dengan meminta murid yang lainnya untuk memberika tepuk tangan kepada kelompok belajar yang melakukan presentasi. Ketika keaadaan kelas sudah tenang kembali, peneliti memberikan kuis (tes) untuk dikerjakan oleh masing-masing murid. Kuis yang diberikan sebanyak 1 nomor. Dengan menggunakan waktu yang tersisa, murid-murid menyelesaikan tes yang diberikan oleh peneliti. Terliat para murid serius ketika menyelesaikan tes tersebut. Setelah selesai mengerjakan tes tersebut, Selanjutnya peneliti memberikan kata-kata pujian kepada kelompok belajar yang tampil pada saat itu sebagai bentuk penghargaan.

Pertemuan ketiga dan keempat siklus kedua ini peneliti memberikan tugas rumah kepada muridmurid. Sebelum menutup kegiatan PBM, peneliti bersama murid-murid membuat kesimpulan mengenai materi yang dipelajari pada saat itu serta peneliti juga menyampaikan materi yang akan dipelajari pada pertemuan selanjutnya. Peneliti menutup kegiatan PBM dengan salam dan doa.

\subsubsection{Observasi Siklus Kedua}

Berdasarkan lembar observasi dan diskusi dengan guru kelas, proses pembelajaran pada siklus kedua sudah berjalan sesuai dengan skenario. Setelah kegiatan PBM selesai, selanjutnya peneliti memberikan tes kemampuan pemecahan masalah (KPM) dan angket minat belajar matematika. Evaluasi pada siklus kedua dilakukan dengan memberikan tes kemampuan pemecahan masalah dalam bentuk uraian sebanyak lima nomor sedangkan angket terdiri dari 30 butir pernyataan. Data hasil kemampuan pemecahan masalah (KPM) siklus kedua dapat dilihat pada Tabel 8. Dari Tabel 8 dapat dilihat bahwa nilai rata-rata kelas yang diperoleh pada siklus kedua adalah 85,71 dengan persentase kentutasan belajar siswa adalah 90,63\%.

Tabel 8. Hasil Tes Kemampuan Pemecahan Masalah Siklus Kedua

\begin{tabular}{cc}
\hline Hasil Siklus Pertama & Nilai \\
\hline Rata-rata & 85,71 \\
Nilai Terendah & 55 \\
Nilai Tertinggi & 90 \\
$\geq 70$ & 29 \\
$<70$ & 3
\end{tabular}




\begin{tabular}{cc}
\hline Hasil Siklus Pertama & Nilai \\
\hline Ketuntasan Belajar (\%) & 90,63 \\
\hline
\end{tabular}

Dari Tabel 9, terlihat bahwa minat belajar matematika siswa pada katagori ST memiliki persentase $28,39 \%$, katagori T memiliki persentase $59 \%$ dan katagori S memiliki persentase $13 \%$.

Tabel 9. Hasil Minat Belajar Matematika Siklus Kedua

\begin{tabular}{ccc}
\hline Kategori & Jumlah & $\begin{array}{c}\text { Persentase } \\
\mathbf{( \% )}\end{array}$ \\
\hline Sangat Tinggi & 9 & 28,39 \\
Tinggi & 19 & 59 \\
Sedang & 4 & 13 \\
Rendah & 0 & 0 \\
Sangat Rendah & 0 & 0 \\
\hline
\end{tabular}

\subsection{Pembahasan}

PTK ini dilaksanakan sebagai salah satu usaha meningkatkan KPM matematika murid-murid dan minat belajar matematika pada mata pelajaran matematika pokok bahasan operasi pecahan dengan menerapkan model pembelajaran PBL dalam seting STAD. Pada penelitin dilakukan empat tatap muka pada tiap-tiap siklus berdasarkan alokasi waktu, dimana pada akhir setiap siklus dilakukan evaluasi sebanyak satu kali pertemuan.

Sebelum melaksanakan siklus pertama, diadakan tes kemampuan awal dan minat belajar matematika. Dari evaluasi diperoleh nilai rata-rata siswa yang mencapai KKM 28,13\% atau dalam kata lain ada 9 murid yang mencapai nilai $\geq 70$. Hal ini dikarenakan siswa belum terbiasa dengan soal-soal pemecahan masalah dan pengetahuan awal murid-murid terhadap materi yang akan di lakukan evaluasi tergolong rendah. Pada minat belajar matematika siswa, siswa yang memiliki minat ST sebesar 0\%, T 13\%, S 34\%, R 38\%, dan SR $16 \%$.

Pelaksanaan siklus pertama pada pertemuan pertama dan kedua dilaksanakan berdasarkan rencana pelaksanaan pembelajaran yang telah disusun sesuai dengan model pembelajaran PBL dalam seting STAD. Setelah pelaksanaan pembelajaran sebanyak empat kali tatap muka untuk masing-masing siklus, dilakukan evaluasi untuk siklus pertama dan pemberaian angket minat belajar matematika siswa. Dari evaluasi siklus pertama diperoleh nilai rata-rata kelas sebesar 60,71 dengan persentase kentutasan belajar adalah 40,63\%. Nilai tertinggi yang diperoleh adalah 80 dan nilai terendah adalah 30. Dari 32 siswa hanya 13 siswa yang memperoleh nilai di atas KKM dan sisanya sebanyak 19 siswa memperoleh nilai di bawah KKM. Sedangkan untuk pemberian angket minat belajar matematika pada siklus pertama dari 32 siswa memiliki minat pada katagori sangat tinggi memiliki persentase $6,25 \%$, katagori $\mathrm{T}$ memiliki persentase $25 \%$ dan katagori $\mathrm{S}$ memiliki persentase $38 \%$ dan kategori R memiliki persentase $31 \%$. Pada siklus pertama keterlaksanaan pembelajaran $92 \%$.

Hasil yang diperoleh pada siklus pertama untuk tes kemampuan pemecahan masalah (KPM) masih tergolong tendah atau indikator kinerja belum tercapai, sedangkan untuk minat belajar matematika pada kategori S dan R perlu ditingkatkan lagi. Hal ini disebabkan oleh beberapa faktor yaitu peneliti tidak banyak melakukan apersepsi dalam pembelajaran; peneliti tidak banyak membuat contoh dari materi ajar pada lembar informasi; penggunaan waktu dalam kegiatan PBM yang kurang baik sehingga mengakibatkan beberapa tahap kegiatan pembelajaran tidak terlaksana; pemberian kuis dan pemberian penghargaan kepada tiap kelompok tidak terlaksana pada pertemuan pertama, sedangkan pertemuan kedua peneliti tidak memberikan tugas rumah karena alasan waktu; terdapat beberapa murid tidak serius dalam mengikuti kegiatan PBM; dan beberapa murid pada kempok belajar terlihat pasif dalam mengelurkan pendapat dan beberapa murid lainnya kurang dalam membantu teman dalam memahami materi maupun menyelesaikan masalah.

Berdasarkan kekurangan pada siklus pertama, peneliti melakukan refleksi yaitu dengan menyusun beberapa rencana pembelajaran selanjutnya yaitu peneliti lebih memperhatikan RPP khususnya dalam menyampaikan apersepsi, tujuan pembelajaran diawal pembelajaran, memberikan motivasi dan pemberian informasi pada lembar informasi; merencanakan alokasi waktu yang lebih efektif; mengoptimalkan pengelolaan kelas terutama saat memahami informasi dan berdiskusi; peneliti lebih mengaktifkan tanya jawab dengan murid-murid pada saat murid-murid memahami informasi; peneliti lebih mampu mengelola kelas dalam mendampingi murid dalam memecahkan 
masalah; pemberian informasi dalam LKS harus lebih jelas; dan mengajak siswa untuk lebih semangat dalam presentasi hasil diskusi.

Siklus kedua proses pembelajarannya dilaksanakan seperti siklus pertama, dengan melakukan rencana-kencana yang telah disusun pada tahap refleksi berndasarkan kelemahan-kelemahan yang terjadi pada siklus pertama. Dari hasil evaluasi siklus kedua, baik dari segi KPM murid-murid maupun minat belajar matematika serta keterlaksanaan proses pembelajaran sudah mencapai indikator kinerja yang ditetapkan, maka PTK ini sampai pada siklus kedua.

Pelaksanaan model PBL seting STAD telah berjalan sesuai dengan rencana yang disusun oleh peneliti, dapat dilihat pada siklus kedua dimana terjadi peningkatan nilai rata-rata dan persentase ketuntasan belajar secara kelompok. Selain itu, peneliti juga sudah dapat menguasai kelas dan menggunakan waktu dengan baik, sehingga pelaksanaan RPP dapat berlangsung lebih baik dibandingkan siklus pertama. Sehingga alokasi waktu yang sudah direncanakan dapat berjalan sesuai dengan yang telah direncanakan. Terlihat peningkatan ketuntasan sebesar 50\%. Disisi lain peningkatan minat belajar siswa juga terlihat dari perbandingan persentase angket pada siklus pertama dan siklus kedua yang mana untuk katagori sangat tinggi terjadi peningkatan sebesar $22,14 \%$ dan kategori tinggi terjadi peningkatan sebesar 34\%. Terjadinya peningkatan nilai rata-rata dan ketuntasan klasikan serta minat belajar, dimana peningkatan ini sudah sesuai dengan inikator keberhasilan yang ditentukan oleh peneliti. Sehingga dapat dikatakan bahwa penggunaan model PBL seting STAD dapat meningkatkan KPM dan minat belajar murid-murid. Oleh karena itu penerapan model PBL dalam seting STAD dapat meningkatkan kemampuan pemecahan masalah dan minat belajar matematika siswa pada siswa kelas V SDN 2 Baubau materi pokok pecahan.

\section{Simpulan dan Saran}

Berdasarkan hasil penelitian dan pembahasan pada siklus pertama dan siklus kedua, dapat disimpulkan bahwa penerapan model pembelajaran PBL dalam seting STAD dapat berjalan sesuai dengan rencana yang telah disusun ketika peneliti bersama guru kelas melakukan perbaikanperbaikan pelaksanaan pembelajaran berdasarkan kekurangan pada siklus pertama, sehingga dapat meningkatkan KPM dan minat belajar matematika murid-murid. Peningkatan KPM yang terjadi sebesar 50\% sedangkan peningkatan minat belajar yang terjadi adalah untuk katagori sangat tinggi terjadi peningkatan sebesar 22,14\% dan kategori tinggi terjadi peningkatan sebesar $34 \%$ dan tidak ada lagi murid yang memiliki minat belajar matematika rendah dan sangat rendah. Karena pada siklus kedua sudah mencapai target yang diinginkan maka penelitian tindakan kelas ini samapai pada siklus kedua.

Berdasarkan kesimpulan di atas, saran yang dapat disampaikan yaitu guru sebaikanya dalam melaksanakan pembelajaran harus menggunakan metode yang bervariasi dan melibatkan muridmurid dalam kegiatan PBM yang berlangsung dikelas maupun diluar kelas untuk meningkatkan kemampuan berpikir murid-murid serta minat mereka dalam mempelajari berbagai hal. Selain itu, para guru sebaiknya sering menggunakan model pembelajaran yang berbeda-beda sesuai dengan materi yang diajarkan, agar murid-murid terbiasa dengan model pembelajaran baru.

\section{Daftar Pustaka}

Ali, R., et al. (2010) Effect of using problem solving metodh in teaching mathematics on the achievement of mathematics students. Journal Asian Social science, 6, 67-72

Bell, F.H. (1978). Teaching and learning mathematics (in secondary schools). Lowa: Brown Company Publishers.

Borich, G. D. (2007). Effective teaching methods: Research-based practice (6 ${ }^{\text {th }}$ ed). OH: Pearson Education Inc.

Brown, H. D. (2007). Principle of language and teaching. NY: Addison Wesley Longman, Inc.

Carlan, V. G., Rubin. R., \& Morgan. B. M. (7 Januari 2016). Cooperatif learning, mathematical problem solving, and latinos. $C \&$ I Departemen, School of Education. Diambil pada tanggal 2 Februari 2016, dari https://www.researchgate.net/publication/252689325 Cooperative Learning Mathematical Problem_Solving_and_Latinos. 
Cheong, F. (2008). Using a problrm based learning approach teach an intelligent system course. Journal of information technology education, 7, 47-60.

Delisle, R. (1997). How to use problem-based learning in the classroom. Alexandria, VA: Association for supervision and curriculum development.

Eggen. P. \& Kauchak. D. (2012). Strategi dan model pembelajaran. (Terjemahan Satrio Wahono). Boston, MA: Person Education. (Buku asli diterbitkan tahun 2012).

Fennema, E., \& Romberg, T. A. (2009). Mathematics classrooms that promote understanding. New Jersey: Lawrence Erlbaum Associates.

Gable, R. K. (1986). Instrument development in the affective domain. NY: Springer Science \& Business Media.

Jaisook, S., Chitmongkol, S., \& Thongthew, S. (2013). A mathematics instructional model by integrating problem-based learning and collaborative learning approaches. Silpakorn University Journal of Social Sciences, Humanities, and Arts, 13, 271-294.

Mergendoller, J.R., Maxwell, N.L., \& Bellisimo, Y. (2006). The effectiveness of problem-based learning instruction: a comparative study of instructional methods and student characteristics. The Interdisciplinary Journal of Problem-Based Learning, 1, 49-69.

NCTM. (2000). Principles and standars for school mathematics. Reston, VA: NCTM.

Rahardi, S. (2011). Perbadingan Keefektifan Cooperative Learning Tipe STAD dengan GI Ditinjau Dari Kemampuan Pemecahan Masalah, Sikap, dan Minat Terhadap Matematika SMP. Tesis Magister, tidak diterbitkan, Universitas Negeri Yogyakarta, Yogyakarta. 